\title{
Towards a Practice of Emancipation in Urban Schools: A Look at Student Experiences Through the Science Genius Battles Program
}

\author{
Edmund Adjapong \\ Educational Studies Department, Seton Hall University
}

\begin{abstract}
This study explores the experiences of high school students who participated science education initiative called The Science Genius Program, which is anchored in Hip-Hop culture. I argue that through participating in the Science Genius Program young people in urban communities are able to develop skills to emancipate themselves from oppressive practices and structures of the science classroom. Participants in this study are high school students who attended urban high schools in one of the largest school systems in the country. Through this study the researcher suggests that students had positive experiences around science, see themselves using the skills they learned through the program to further their learning and were able to develop positive relationships with community members and teachers through their participation in the Hip-Hop based science program.

Keywords: urban science education, hip-hop education, teaching and learning.
\end{abstract}

\section{Introduction}

Reflecting on my experiences as a child who attended public school in the largest urban school district, in the country, I would have never imagined myself in my current position as a STEM educator, teacher educator and educational researcher. My experiences as a student in public schools were at times daunting, traumatic and unexplainable. As a student of color, very seldom did I feel comfortable and fully self-actualized in school (Maslow, 1965). Rather, I often felt misunderstood and misrepresented by teachers and even disconnected from the physical space of the school. I was disengaged from the process of learning, especially in the science classroom. While attending public schools, I felt as if teachers did not understand who I was or the multiple identities that I brought into the school building as a Black boy from an urban community and immigrant family. The negative feelings that I carried while into school had a direct and adverse impact on my learning because even while I was physically in a school building, I felt like education and the process of learning were inaccessible (Basu \& Barton, 2007).

Upon graduating from college, I made the decision to teach in the same urban community where I attended school because I realized that students of color continue to have experiences that were similar to mine while attending public schools. My experience as a disengaged student in urban schools and my observations of disengaged students in urban schools are not unique experiences for urban youth. Studies show that students of color from urban educational settings are often disengaged and find themselves alienated from schools and the process of education as a whole (Andrews, 2017; Dei, Mazzuca \& McIsaac, 1997; Felice, 1981; Ford \& Harris, 1996; Howard, 2013; Jaudinez, 2019; Ogbu, 2003). As a result of feeling disengaged and alienated from schools, many studies (Linn, Lewis, Tsuchida, \& Songer, 2000; Teale, Paciga, and Hoffman, 2007) suggest that students of color and students from underrepresented groups in urban communities face poorer educational outcomes and fall behind their White counterparts beginning in the 4th grade in science, and math due to limited instruction time, socioeconomic factors and failure to use students' context to anchor instruction (Lieberman \& Hoody, 1998). Studies have also demonstrated that urban students are less likely to be interested in the sciences partially because educators misunderstand their experiences and as a result, are not able to demonstrate the relevance of science (Kahle, Meece, \& Scantlebury, 2000; Seiler, 2001; Erbilgin, 2017; Boutelier, 2019). Emdin (2010a) described urban students' lack of engagement in urban schools, specifically in science classrooms, as an aversion for learning science.

According to Munce and Fraser (2012), African-American students' interests in STEM has decreased significantly over time, is now lower than any other ethnic group, and is expected to remain low in upcoming years. Additionally, there is an achievement gap in science between African-American and Latinx urban students relative to their counterparts of other ethnic groups, including those in rural settings. Yet, there continues to be an ongoing misunderstanding about, and I argue lack appreciation of, the culture, experiences, and realities of African-American and Latinx students who predominantly populate urban settings (Kahle et al., 2000; Seiler, 2001). Scholars such as Ladson-Billings (1995) and most recently Paris and Alim (2017) have argued for culturally relevant and sustaining pedagogies. In Science Education, scholars like Atwater (1996) and Emdin (2016) speak directly to the ways that culture may be a powerful aspect of science teaching and learning when 
appropriately aligned with the prevailing social and aesthetic interests of urban students. In order to gain insight into urban students' experiences as a way to better engage them in the science classroom, I argue that educators must identify innovative approaches to teaching science that incorporates and authentically acknowledges the culture of students. Among these are culturally relevant approaches that "focus explicitly on understanding the realities of youth within urban classrooms and supports the teacher in utilizing an understanding of these realities as an anchor for instruction and delivery" (Emdin, 2011, p. 5), therefore moving away from oppressive pedagogies and practices, which are known to disengage urban students from science. Conversely, I argue, that educators and school leaders not working toward authentically understanding and utilizing students' culture, lived experiences as an anchor of engagement within schools and classrooms, contributes to the negative outcomes associated with schooling which urban students face, including lower scores on standardized exams, low attendance, dropping out, and disproportionate school discipline practices (Allensworth \& Easton, 2007; Kotluk \& Kocakaya, 2018; Reardon, 2011; Ruck \& Wortley, 2002, Skiba, Michael, Narbo, \& Peterson, 2002; Townsend 2000).

Due to an increasingly competitive global economy, there has been a specific emphasis on improving student outcomes in science, technology, engineering and mathematics (STEM) in recent years to prepare young people for jobs in STEM fields (Breiner, Harkness, Johnson, \& Koehler, 2012). In particular, initiatives launched by the White House of the United States of America, have placed an emphasis on (STEM). Former President Obama created many STEM initiatives to support the academic achievement of American youth in STEM. In 2015, President Obama announced over \$240 million to prepare students to excel in the STEM fields, especially those from underrepresented ethnic groups (Fact Sheet, 2015). Reports show STEM occupations are projected to grow by 17 percent from 2008 to 2018, compared to 9.8 percent growth for non-STEM occupations (Langdon, McKittrick, Beede, Khan, \& Doms, 2011; Márque, Peña, Jones, Orange, \& Simieou, 2018).). Concurrently, African American and Latinx students' interests in STEM has decreased significantly and is now lower compared to their ethnic counterparts and is expected to remain lower during the coming years (Munce \& Fraser, 2012). Therefore, due to a lack of interest in STEM, especially by students of color, they will not acquire the skills needed to compete for future STEM jobs, and ultimately there will be fewer jobs available for them. In order for urban students to successfully compete in the competitive global economy, science educators must utilize innovative approaches to teach and engage students, especially underrepresented students, in science.

For urban students to be prepared to meet the demands of our countries competitive global economy as it relates to careers in STEM, particularly science, I argue that we must interrogate the ways in which we engage all youth in science, especially urban youth. In this paper, I share a framework for the Science Genius Battles program, a non-conventional science education program that utilizes Hip-Hop culture as a tool to engage urban youth in the sciences. In this study, I seek to answer the following research question: What are the experiences of urban youth who participate in the Science Genius Program? I focus on the experiences of participants of the Science Genius Battles program to understand how this innovative approach to teaching science transforms students relationships with learning the discipline of science. Further, I argue that approaches used by and The Science Genius Battles Program can be identified as a form of emancipatory pedagogy, as it creates a transformative educational experience that produces a shift in how urban students view, think, and approach the traditionally Eurocentric discipline of science (Nouri \& Sajjadi, 2014; Speir \& Simmons, 2016; Woofter, 2019).

\section{Conceptual Framework \\ Decolonizing Urban Schools Framework}

This study is rooted in a decolonizing framework as described by Smith (2013). In her work, Smith (2013) suggested that researchers and scholars have traditionally favored imperialistic ways of knowing developed primarily by Westerners. In other words, those in power, those who have colonized and marginalized other groups of people, have privileged their ways of knowing and constructing knowledge, especially in schools. Privileging the dominant group's ways of knowing promotes a lack of consideration of marginalized groups' ways of knowing, which I argue if often different from the dominant groups, especially if the dominant group and marginalized group do not follow the same culture or belief systems (Yehya, Barbar \& Abou Rjeily, 2018)

When considering the history of public schools in the United States, scholars recognize Horace Mann as "the father of public schools." Horace Mann was the first person appointed to the position as Secretary of the Massachusetts Board of Education in 1837. This afforded him the opportunity to share and spread his vision for the common school, which was created with the aims to "mitigate class conflict, circumvent anarchy, enhance civic engagement, and perhaps most importantly inculcate moral habits, all by molding society's most malleable members" (Warder, 2017, p.1). In his process of spreading his vision for public education, Horace Mann, a 
White man, and his White counterparts sought to mold "society's most malleable members," young people in schools, into the image of their liking which resembled White values and culture (Mauch \& Tarman, 2016; Moore, 2018; Tyack, 1974). During the mid-1800's, the American people followed and agreed with Mann's philosophy of schooling. The public praised the common school as a school system that was created to instill common values among people and that would contribute to a new type of public stability (Tyack, 1974). Large cities across the country began to replicate Horace Mann's model of schools and began to create schools that developed students who instilled the same common values, which were traditional English beliefs of family, church, community, and apprenticeship (Cremin, 1970). Students whose cultures and lived experiences did not align with that of the dominant culture's, traditional English beliefs, were forced through public schooling to adhere and assimilate to the values of the dominant culture. At its very conception, public school systems were not created to consider nor value the culture of less dominant groups of people whose cultural beliefs and practices exist and differ than that of the dominant group. Now, nearly two centuries after the conception of the common school system, public schools continue to operate without a true consideration of the values of groups of students who have historically been pushed to the margins of society, including urban students who identify as part of the Hip-Hop generation (Adjapong \& Emdin 2015).

In this study, I acknowledge and pay reference to indigenous populations as a group that has historically been marginalized, colonized and therefore considered a less dominant group as perceived by society. Similar to Emdin (2016), I draw parallels between indigenous populations and urban youth, especially those who identify as part of the Hip-Hop generation. Urban youth, who often identify as students of color, would also be categorized as a less dominant group as perceived by society because similar to indigenous populations, people of color in the United States have been victims of slavery, Jim Crow Laws and disproportionate incarceration rates. Despite the explicit connection that indigenous and urban populations have to specific territories and natural surroundings, there are other connections that can be made between indigenous populations and urban youth (Emdin, 2016). More obvious connections revolve around how urban youth, similar to indigenous populations, are traditionally known to construct knowledge differently (Moje, Ciechanowski, Kramer, Ellis, Carrillo, \& Collazo, 2004; Maguth, Koskey, 2019), follow and identify as part of a different culture than the dominant group, communicate with one another differently than dominant groups and follow a different set of beliefs than the dominant group. Most importantly, we must consider how urban youth have suffered from targeted and systemic oppression, similar to most North American indigenous groups. Specifically, we must consider how urban youth have been marginalized as a direct result of decisions made by the dominant group.

My intention to make connections between indigenous populations and the Hip-Hop generation is not meant to draw attention away from indigenous studies and research. My goal is to draw a comparison between indigenous populations and urban communities, by highlighting the collective oppression that both groups experience at the hands of the dominant group. Smith (2013) posits that proving the validity of indigenous knowledge, including "that indigenous peoples have ways of viewing the world which are unique," is not the only challenge indigenous populations face, but also proving the authenticity and control over those forms of knowledge (p. 104). These are similar challenges found with the Hip-Hop generation who often have different experiences than the dominant group due to the differences in lived realities and beliefs, which encourages them to construct knowledge and view the world differently. Because researchers have discovered that urban youth and the Hip-Hop generation construct knowledge and view the world differently, there has been a push for educators to use culturally relevant pedagogies and practices, especially when engaging urban youth (Brown, 2003). The Hip-Hop generation identifies with the five creative elements of Hip-Hop (MC, B-boy/B-girl, graffiti, deejay, and knowledge of self) which guide their experiences and the unique way in which they view the world. The Hip-Hop generation often communicate and engage with one another using alternative colloquialism, commonly known as slang, when engaging their peers as Smith (2013) also highlights that indigenous populations "often have their own language or code" (p. 127).

Public schools were founded upon the idea of encouraging young people whose culture do not align with that of the dominant group to assimilate, through the process of schooling, to that of the dominant culture. I argue that students in urban schools carry multiple identities with one of those identities oftentimes being a Hip-Hop Identity (Adjapong \& Emdin, 2015). Oftentimes, students attend urban schools that demonstrate little to no representation to any of the students' cultures (Ford \& Harris, 1996). Through participating in a sciencebased program, The Science Genius Program, which is anchored in Hip-Hop culture, urban students, are provided with an opportunity to engage in science, a historically Eurocentric dominated discipline, while expressing themselves using a culture and art form in which they identify with. I maintain that The Science Genius Program can be identified as an educational initiative that supports the decolonization of urban public schools and therefore demonstrates the possibilities emancipating youth within traditional educational systems. 


\section{Sociocultural Framework}

This study is also rooted in a sociocultural framework that explores the concepts of culture and social capital as they relate to the experiences of African- American, and Latinx urban students in their urban science classroom. Vygotsky states that "human activities take place in a cultural context, [and] are mediated by language" (John-Steiner \& Mahn, 1996, p. 191). Most urban students' experiences outside of school are rooted in Hip-Hop culture (Emdin, 2010). The ways urban students dress, the ways they talk, the ways they dance and other non-verbal forms of communication are all rooted in Hip-Hop culture. Authentically incorporating HipHop culture into urban science classrooms via the Science Genius Program can provide opportunities for urban youth to construct an understanding of science content using their culture. If students are engaged and excited about science content in the classroom, and their exchanges around the content are occurring with the use of hip-hop forms of communication, over time, students they take on increasing responsibility for their own learning (John-Steiner \& Mahn, 1996; Lave \& Wenger, 1991).

For this study, I also draw insight from sociologist Bourdieu (1986) who described capital and its varied forms as necessary for articulating the ways that humans exist in a social world. In particular, I focus on the form of capital that is acquired in social fields like classrooms when individuals develop a conscious or unconscious personal investment in an activity or process. This form of capital is called "cultural capital" and in its embodied state, is both inherited and acquired as one engages with either new or familiar tools in an activity. In other words, a student may possess forms of cultural capital outside of the classroom, and then use these forms of capital to acquire new forms of knowledge within the classroom. The goal is for science educators to create contexts that generate new forms of cultural capital that will eventually lead to the acquisition of science content knowledge. If students develop more opportunities to expand their cultural capital within their science classrooms and around science content, they will not only be more prepared to navigate science spaces outside of the science classroom, but they will also be more comfortable and empowered while navigating these spaces. Hip-Hop is a form of cultural capital that many urban youths possess. When brought into science classrooms, and used as a viable form of knowledge acquisition, it can be used to expand youth cultural capital to include science. Students who develop more cultural capital within the science classroom may be more likely to take on a science identity because both Hip-Hop and the teaching approaches being employed in the classroom are connected to their lived experiences. In this type of scenario, students are accumulating and exchanging cultural capital both in Hip-Hop spaces outside of the classroom and within the classroom. Bourdieu (1986) described cultural capital as having an unconscious and non-deliberate quality in terms of how the individual generates it. However, he also described cultural capital as something gained as the result of "conditions of acquisition." I suggest that science classrooms that allow and welcome the expression of Hip-Hop culture are the ideal spaces for the "conditions of acquisition" for urban youth who identify as Hip-Hop to use the cultural capital that they gained as identifying as of part Hip-Hop culture. I also argue that through students experiences in the Science Genius Program, they will gain cultural capital, as it relates to science, which in its embodied state, is both inherited and acquired as one engages with either new or familiar experiences. I argue that students will gain cultural capital in science because they are able to connect and make connections between their culture (HipHop) and science content. This could encourage students to draw connections between science content and HipHop culture, which in-turn could support students learning and understanding of science content. If urban youth are encouraged to learn science utilizing through a practice anchored in their culture, then they will be more comfortable navigating science spaces and classes outside of their participation with the Science Genius Program.

\section{Methodology \\ The Science Genius Program}

In this study, the Science Genius Battles program was created to serve as an intervention for urban youth in science classrooms. The main activity of the program involves the writing and performing of science content-themed raps or spoken word poems, with an opportunity for students to engage in a competition/battle to showcase their science-themed songs. For this study, the Science Genius Program was implemented in ten urban public high schools and was launched in low-income communities in a densely populated northeastern city in the United States of America. Students who participated in the Science Genius Program were high school students of various ethnic backgrounds who were large of Latinx and African-American descent. All participating youth reported that they listened to or engaged in Hip-Hop music/culture or one of its elements (e.g. b-boying, deejaying, tagging/graffiti, MCing/rapping).

Participating schools were selected based on their historical underperformance of students in science and a willingness to explore an innovative approach to addressing the aforementioned issues. Each participating school offered students at least two science courses (i.e. Chemistry, Living Environment, Earth Science or 
Physics) toward their graduation requirements. According to the Department of Education, each school that participated in Science Genius Program reported an lower pass on standardized science exams as compared to the state average.

Each school had at least one dedicated science educator committed to implementing the program in their science classroom. The science teacher dedicated at least one science period per week to the program following a prescribed curriculum that provided the opportunity for students to craft science-themed songs or spoken word poetry based on the science content being taught in the science class (eg. biology, chemistry, physics or earth science). Participating teachers were provided with a guide that outlined the elements of HipHop and ways to include its' five elements (graffiti art, MCing, breaking, deejaying and knowledge of self) into the science classroom and professional development training on implementing the curriculum and how to authentically engage in youth culture. Over the course of the academic semester, students were guided on how to write raps and/or spoken word poems around the science content that they was taught in their classes. In addition to providing a class period per week for students to work on their raps, teachers served as science content experts to students as they wrote their raps. Students were encouraged to make connections between the science raps they were writing and their lived experiences and to continue working on their raps and poems even after they left the classroom.

After the semester, the program concluded for all participants across schools with a culminating event, The Science Genius Final Battles, where each participating school sent a student who was selected by their peers to represent their school in a rap competition/battle where they performed their science-themed rap or spoken word poem in front of a crowd of peers, scientists, Hip-Hop artist and community members. Students who were selected by their peers to represent their schools were invited to an ivy league college where they worked with community members, who served as Hip-Hop ambassadors, to prepare for their Science Genius Final Battles performance. During the Science Genius Final Battles, students' performances were judged by working scientists and established Hip-Hop artists on their overall quality, stage presence and science content. Students are assessed by the judges based on criteria that included connections to lived and emotional experiences, the song's ability to capture an audience, accuracy and rigor of science content and the depth/quality of the science content. At the Science Genius Final Battles, community members, parents, school leaders from across the city and all students from each participating school was invited to celebrate and cheer for students as they demonstrate the science content knowledge through a Hip-Hop.

\section{Participants}

While participants in the Science Genius program included students across ten urban public high schools, the six participants (four girls and two boys) of this study were high school students who were selected by their peers to represent their schools at the Science Genius Final Battle Each of the ten urban schools that participated in the Science Genius Program were Ties. Each student who participated in this study was enrolled in a science class (e.g. biology, earth science, chemistry, physics) as a part of their graduation sequence. Out of the 18 students in total who were selected by their peers from the 10 participating schools to compete at the Science Genius Final Battles for having the best science-themed raps, only 6 students consented to participate in this study.

\section{Research Question}

1. What are the experiences of urban students who participate in the Science Genius Program?

\section{Data Collection Methods}

The primary data source for this study was student one-on-one interviews. Secondary sources included field notes, video vignettes of students' performances and observations of students while participating in the Science Genius Program, both prior to and after the competition. Participating students gathered for a final celebration for all Science Genius students and were individually interviewed about their participation and experience with the Science Genius Program. The student interviews were conducted within one week of their participation in the Science Genius Final Battles. All student interviews were transcribed in their entirety.

Student Interviews. High school students who participated in the Science Genius Program were interviewed about their experiences during the program, and about their experience participating in the competition. The goal of the interviews was to understand the impact that the Science Genius Program had on students' lives and science identities. Among the questions asked during the interviews, the following questions were particularly significant for this study:

- What are some experiences you had during participating in the program? 
in the future?

How do you think your participation in the Science Genius Program will help you in school

\section{Data Analysis Methods}

Different data analysis strategies were used to efficiently and effectively analyze data collected during this study. Student interviews were the primary data source for this study. Secondary data sources include participant observations, field notes and video vignettes of student performances. Interviews of participating students were transcribed in their entirety and reflective field notes will be taken during and after each focus group. These datasets were then coded for exemplars of that demonstrated students experiences while participating in the Science Genius Program.

Qualitative research techniques, including member checking and coding for recurring themes, were used to analyze all the data generated from this study (Creswell, 2013; Guba \& Lincoln, 1989). All interview data was entered into a Word document for word-by-word coding for emergent themes. Once categories were identified, the data was then entered into NVivo to be organized and grouped into recurring themes. The three themes that emerged from data analysis were:

(1) Empowering Experiences through Participating in The Science Genius Program

(2) Using Hip-Hop to Support Future Learning

(3) Students Connection to Community Members \& Teachers through the Science Genius Program

Reliability, Validity, and Trustworthiness. The use of multiple qualitative methods to collect data ensured the validity, reliability, and trustworthiness of this research project. To ensure that I took an objective approach to the analysis of the data of this study, I utilized qualitative research methods that provided an opportunity for participants to share their narratives. Video vignettes of student performances provided an additional opportunity to make observations of students experiences during the study. To further demonstrate reliability, direct quotes from students' interviews are included in the presentation of this study. Adding to the trustworthiness of this study, I utilized member checking as an approach to ensure that all participants interviews were being interpreted within the appropriate context and not solely through my experiences as the researcher (Shenton, 2004). To conceal the identity of participants of this study, each student was given a pseudonym when mentioned in the discussion.

Consent and Ethical Considerations. This study involved minimal risk. Each student voluntarily participated in the study and completed informed consent documents. Students received a grade for their participation in the Science Genius Program, which was given by their science teacher using a rubric with a predetermined criteria. Students did not receive any incentives for participating in this study. Students did not receive preferential treatment during the study and participation in this study did not impact their grades. Students were able to opt out of participating in this study at any time.

\section{Results and Findings}

The findings of this study are organized by recurring themes that emerged during the data analysis process. To elaborate on recurring themes, selected exemplary moments from transcripts were chosen to provide insight on student's experiences with the Science Genius Program, both individually and collectively, and in turn demonstrate the benefits of the innovative science education program.

\section{Empowering Experiences through Participating in The Science Genius Program}

Through interactions with participants, including observations and interviews, there were many instances when participants described positive and empowering experiences from participating in the Science Genius Program. Through participating in the Science Genius Program, an initiative that engages urban youth using Hip-Hop culture, students shared experiences of becoming empowered and gaining confidence amongst themselves while engaging in science content. When asked about his experience in the Science Genius Program, Alex, a Science Genius Finalist shared,

We're all young, we all wanna have fun, and obviously when incorporating Hip-Hop, I think I can speak for everyone here when I say that this was a fun experience. And it involves science... We have the choice to choose the beat, we have the choice to choose our subject, we have the choice to choose our lyrics, we have all the choices, and I think that's what's most important.

Alex shared that incorporating Hip-Hop in the science classroom provided him and his peers with a "fun experience" around engaging in and learning science. Further, Alex, reveals that having the freedom of choice while participating in Science Genius activities was one of the most pivotal experiences for him. The 
Science Genius Program promotes student choice in learning as students are allowed the freedom to take full creative control of their science-themed raps. Students are allowed to choose the music that they use in their song and the specific science topic that their songs will focus on. This allows students to use music that is relevant to them and science content that they would like to independently explore further through the creation of science-themed raps. This practice moves away from traditional teaching, which promotes a one-size fits all model and provide opportunities to for students in the urban classroom who have different identities and learning styles to make learning personal (Gašević, Dawson, Rogers, \& Gašević, 2016). Students are encouraged to make deep connections between their lives, personal experiences and science content (Emdin, Adjapong \& Levy, 2016). Similar to student-centered learning environments, the Science Genius program provides opportunities for students to empower themselves and to take control of their own learning (Hannafin, Hill, \& Land, 1997; Hannafin, Hill, \& Land, 2014). Studies show that the ultimate outcome of student-centered learning is an increased understanding of a topic, higher level reading, and an increased motivation to learn, in this case, science (Bell, 2010).

Students also reported that participating in the Science Genius Final Battles allowed them to gain confidence to perform their science-themed raps, and in turn demonstrate their understanding of science content, in front of crowds of community members and peers. When describing how she felt during her performance at the Science Genius Final Battles Gloria shared,

So you see how everybody wasn't in their comfort zone. That's one thing science genius taught us, is that you're not gonna always be in your comfort zone, but you're gonna have to work through that. I don't know, I just pushed [through], this is not my comfort zone, but let me make it be my comfort zone. It gave me the strength for us, everybody. So thank you, Science Genius.

Gloria explains that she observed that other students were not fully comfortable while performing their science-themed raps at the Science Genius Final Battles. Gloria shared that participating in the Science Genius Program taught her to work through the discomfort she felt while participating in various Science Genius activities. Gloria thought it was appropriate to push through her discomfort to reach a space of comfort where she found strength around engaging in science content. Through engaging in science content utilizing Hip-Hop culture, urban youth find ways to overcome obstacles around learning that they otherwise would not have the motivation to overcome due to the lack of engagement from traditional science teaching practices. Although students may have felt uncomfortable at moments while participating in various Science Genius activities they may have been able to find comfort through the programs direct connection and emphasis to Hip-Hop, a culture that urban youth identify with (Adjapong, 2017). Christy also shares her experiences participating in the Science Genius Final Battles,

When I came to rehearsals at in the last minute I honestly thought that I could not do it. I had no preparation or energy, I was shy, I did not what to practice my song, I was on the verge of tears and just being on the stage made me scared. Science Genius to me is more than teaching me about science and stuff. It gave me confidence that I should have had when I was 17 years old, but I didn't. But it finally gave me that confidence to know that I'm able to do things that people, number one, they don't think I can do. And that I'm able to get over fears that I've had. So in that way, that's how I feel. I feel very empowered in that way and I feel I can tell other kids that they can do the same thing that I did.

The Science Genius Program hosted rehearsals to support students who participated and performed in the Science Genius Final Battles. Initially, Christy missed the first few rehearsal sessions, and once she attended she felt intimidated that other students had more time to prepare for the competition. Seeing competing students pushed Christy to the verge of tears, but through practicing, she gained the confidence to prepare with the time she had remaining and competed in the Science Genius Final Battles. This newfound confidence encouraged Christy to voice her positive experience with the Science Genius Program with other students who may lack confidence as it relates to education. As stated earlier, urban youth are more likely to face the negative outcomes associated with schooling including lower scores on standardized exams, low attendance, dropping out, and disproportionate school discipline practices (Allensworth \& Easton, 2007; Corprew \& Cunningham, 2012; Reardon, 2011; Ruck \& Wortley, 2002; Skiba et al., 2002; Townsend 2000). Gaining a new sense of confidence and sense of empowerment by participating in the Science Genius Program can support urban youth and provide the endurance necessary to successfully navigating a historically oppressive school system where they are more likely to face challenges.

\section{Using Hip-Hop to Support Future Learning}

In addition to the positive experiences as described by students while participating in the Science Genius Program, many students shared how engaging in Science Genius activities that were anchored in HipHop culture will support them in future learning endeavors, especially as it relates to science content. When 
students were asked if they thought their participation in the Science Genius Program will help support their learning in the future Alex shared,

I feel like I'll forever incorporate science into raps because this was such an amazing experience that I've had personally. I believe this would help me in college because I don't do well with studying. I can't study, I've been so distracted. But since Hip-Hop is something I enjoy, I see myself taking this and using it farther than just high school.

Alex explained that due his positive experience in the Science Genius Program he will "forever incorporate science into raps, " even in college. He suggests that creating science raps will be an effective way of studying science content once he attends college. In this instance, Alex did not share that he plans on declaring science major when he attends college, but he does recognize that if he does encounter science in the future, he now possesses an effective method and skill that he can access that will support in the deepening his understanding of science content that is authentic to him, which demonstrates an increased responsibility for his own learning (Hannafin et al., 1997; Hannafin et al., 2014; John-Steiner \& Mahn, 1996; Lave \& Wenger, 1991). The goal of the Science Genius Program is not for every student who participates to become a scientist, rather for students to gain the tools necessary to uncover and deepen their learning of science, and therefore ultimately understand that they can be successful if they choose to pursue science as a career. Another goal of the Science Genius Program is to counter the narrative that urban students "envision the field of science as distant and inaccessible" (Basu \& Barton, 2007, p. 467). Similar to Alex, Devon shared,

I definitely see myself taking music and science to college, and science genius taught me that I can do what I like, I listen to hip-hop every day, and my teachers show me how incorporate education to it. It's just a better way of me learning what I need to learn. If I had a quiz two weeks from now, I would start writing a rap now. I'd play that music over and over, it gets stuck in my head, so if I can be just taking a test, and then I forget a topic, and then the song just comes up in my head. And I'm, oh, yeah. And then you're just breezing through the test like, whoa. I got it.

Similar to Alex, Devon shared that he too sees himself using Hip-Hop to support his learning in the future, but not only in science. Devon shared that he would engage in the practice of writing raps to better understand content in all subject areas once he arrived to college and acknowledges that it is a better way for him to learn. He also shared that "science genius taught me that I can do what I like, I listen to hip-hop every day." Through the Science Genius Program, Devon realized that he did not have to negotiate his identities (HipHop identity and school identity) in order to be successful in school. Devon realized that he could harness his appreciation for a deep connection to Hip-Hop culture to learn science and possibly other content of other subject areas as well.

Devon was not the only student who expressed that he could use the skills gained from the the Science Genius program in other content area courses. Genesys shared,

After Science Genius, there was a chemistry and the teacher was like, you could make a timeline or you could make a story or monologue as options. And rapping wasn't an option, but I asked her to make it an option, because that was the easiest thing for me. I asked if can I make a rap about it? And she was like, if that's what helps you.

Genesys had the agency to ask her chemistry teacher to alter her project to allow her to submit a rap as opposed to a timeline or a monologue. After participating in the Science Genius Program, Genesys similar to other students, realized that using Hip-Hop to write content-themed raps was an effective method of learning for her. Genesys asked her teacher to allow her to submit a science-themed rap for her project because she felt that it was it was an effective alternative that will help her gain a deep understanding of the content in an engaging manner as opposed to the other options presented. Science Genius not only acts as an initiative that decolonizes traditional educational spaces through its incorporation of Hip-Hop culture within traditional science curriculum, but it also serves as a conduit to emancipate students as it relates to teaching and learning outside of the science classroom and in other content areas. Once students engage in the Science Genius Program, students realize that they can use the same or similar methods that they were exposed to through Science Genius Program to support their future learning and therefore freeing students from the oftentimes mundane practices that they are traditionally exposed to in schools. It is vital that students are self-motivated to extend their learning, but it is also imperative that students are armed with tools for learning that are anchored in their culture they can relate to, that they enjoy, and that they can access on their own. Through the Science Genius Program, I argue that urban youth are emancipated as it relates to learning because they are provided with an alternative method to acquire and construct science content knowledge within educational structures that have historically oppressed them (Moje et. al., 2004). Further, once students are self-motivated as it relates to learning science content, they will more likely feel comfortable in engaging in science courses and spaces in the future. If students decided to engage in science after high school, they will already be equipped with an 
increased cultural capital around science that will allow them to navigate science spaces more easily (Bourdieu, 1986).

\section{Students Connection to Community Members \& Teachers through the Science Genius Program}

As mentioned earlier, once the student finalists are selected from each participating school they attended rehearsal sessions to prepare them for the Science Genius Final Battles (the cumulative competition event). Students attend rehearsals at an ivy league institution of higher education and interact with community members and the Science Genius Administrators who served as mentors as they prepared for the final battle. Courtney describes her experience of attending rehearsal sessions and make recommendations for teachers by sharing,

When we began coming to Liberty University and were with Brandon and Derrick. They had all these people doing all this science stuff and being lit at the same time. It was just like, alright, let me match your energy. Everyone, just reciprocated that energy. Whenever there's a certain mood across an area, it spreads and makes us feel safe.

Courtney described the energy during the rehearsal sessions as 'lit', which is slang for being overly exciting. Rehearsal sessions were where students would practice their science-themed raps and work with HipHop coaches (Brandon and Derrick) from the community. Courtney shared that seeing other students and HipHop coaches excited in regards to their science-themed performances made her overly excited to practice her science-theme song. She shared that the "energy" around science and science-themed performances spread throughout the space and made her feel safe. During rehearsal sessions, Courtney was provided an opportunity to engage with Hip-Hop coaches from her community and to engage with students who were from different schools who all were collectively overly excited about science and the students science-themed songs. Through this collective excitement, students and community members shared what Courtney describes as 'energy.' The 'energy' that was shared during rehearsal sessions can be described as a positive collective effervescence, which is a sociological construct created by French sociologist Durkheim, where participants in the same community come together and simultaneously engage in the same action, and experience the same social force (Cottingham, 2012; Rawls, 2004; Throop \& Laughlin, 2002).

Further, Christy shared the role that her science teacher played in her Science Genius experience,

I feel like the reason why I was so religious to Science Genius because I love my teachers and I love the fact that they were so engaging when we were doing Science Genius. A lot of teachers they don't know how to connect with us and it's not their fault because we aren't on the same boat.

Here Christy shares that her 'religious' commitment to the Science Genius Program stemmed from her relationship with her science teacher. She explains that her science was engaging while implementing the Science Genius Program. Christy also recognizes that many teachers that she's interacted with may have trouble connection with students because of their differences, noting that "it's not their fault because we aren't on the same boat" and speaking indirectly to the racial disparities that we notice among teachers and how they often don't reflect the population of students (U.S. Department of Education, 2016). Through professional development, Science Genius administrators and researchers focus on how teachers can increase engagement in their science classes even outside of the Science Genius Program. It's believed that urban youth should have access to engaging and effective science instruction even outside of the Science Genius Program.

\section{Conclusion and Implications}

The goal of this study was to uncover the experiences of urban youth who participated in an innovative science education program/intervention that was anchored in Hip-Hop culture. The Science Genius Program's use of Hip-Hop as a conduit to convey science content is intentional, when working with urban youth because it is a culturally relevant approach that reflects the authentic culture of students and allows students to see themselves within the content. Furthermore, incorporating Hip-Hop into the science classroom provides educators an opportunity to legitimize students' culture which historically has been absent from educational spaces (Emdin, 2010b). Through participating in the Science Genius Program students were exposed to alternative approaches to learning anchored in their culture, which they believed could benefit and promote future learning. While students highlighted empowering experiences while participating in the Science Genius Program, they also described having positive connections with their teachers and Science Genius Hip-Hop ambassadors.

The results of this study demonstrates that the Science Genius Program, as an initiative, provides positive experiences for urban youth as it relates to science learning, which is a step in the right direction in improving outcomes for urban youth and is remarkable given the current landscape of science education as it relates to underrepresented groups. Through this study, researchers realized that through using Hip-Hop culture, the Science Genius Program provides opportunities and encourages urban youth to engage in and explore science 
even after their participation in the program and possibly during college. Through using Hip-Hop as a culturally relevant tool, we argue that urban students gain cultural capital as it relates to science and may find themselves self-electing to take science courses or engage in science experiences. Through the Science Genius Program, students experienced empowering moments and developed positive relationships with teachers and community members, which support students' comfortability and affinity for science as a content. In this study, students of color who have attended historically oppressive urban public schools that are known to exclude the culture of urban youth have been provided with a tool and an approach anchored in their culture to support their science learning. This provides students with the opportunity to take charge of their own learning, through using a tool/approach that they are familiar with through their culture, when they graduate secondary school and attend institutions of higher education, which are also known to have historically oppress students of color. Through the Science Genius Program, urban youth gain a tool/skill that can be used to emancipate themselves from the oppressive nature of public schools and have the option to take control of their learning within and outside of the science classroom.

The fact that this study positively impacted teaching and learning in an urban science classroom holds tremendous value for urban learning, teaching and research in a subject area where achievement gaps are most prevalent. However, although urban science classrooms served as the setting for this study, we believe that the framework for Science Genius Program can be beneficial when utilized in other content areas and internationally. Although Hip-Hop is well known for its conception in the Bronx, NY, it is not the most consumed genre of music and identified as a culture that is celebrated globally. Hip-Hop is was created with various intentions, but its main goal is to be a voice for the voiceless, those who have been systematically oppressed and pushed to the margins of society (Emdin, 2010). I argue that wherever there are oppressed people there is a variation of Hip-Hop close by that can be used to anchor instruction in schools to engage young people. Therefore, this study can be applied internationally. This motivates us to engage in future work that moves beyond the small population of students that is the focus of this article, and towards comparative studies among classes in different subject areas where the framework of the Science Genius Program is used. This article, and the burgeoning area of research that births it, shows that approached to teaching and learning anchored in HipHop have the potential to transform classrooms and generate new forms of cultural capital for urban students (Adjapong, 2017). Once Hip-Hop based approaches to teaching and learning that focus on practical aspects of pedagogy become rooted in our practice and research, new opportunities for students are opened, and educators collectively move towards more equitable and transformative experiences for young people.

\section{References}

Adjapong, E. S., \& Emdin, C. (2015). Rethinking pedagogy in urban spaces: Implementing hip-hop pedagogy in the urban science classroom. Journal of Urban Learning Teaching and Research, 66(11), 66-76.

Adjapong, E. S. (2017). Bridging theory and practice in the urban science classroom: A framework for hip-hop pedagogy in STEM. Critical Education, 8(15), 1-15.

Allensworth, E. M., \& Easton, J. Q. (2007). What Matters for Staying On-Track and Graduating in Chicago Public High Schools: A Close Look at Course Grades, Failures, and Attendance in the Freshman Year. Research Report. Retrieved from https://www.air.org/sites/default/files/downloads/report/NHSCCCSRSpecialEd_0.pdf

Andrews, K. (2017). Culture, Curriculum, and Identity in Education. [Book Review]. Journal of Ethnic and Cultural Studies, 4(2), 99-101.

Atwater, M. M. (1996). Teacher education and multicultural education: Implications for science education research. Journal of Science Teacher Education, 7(1), 1-21.

Basu, S. J., \& Barton, A. C. (2007). Developing a sustained interest in science among urban minority youth. Journal of Research in Science Teaching, 44(3), 466-489. doi: 10.1002/tea.20143

Bell, S. (2010). Project-based learning for the 21st century: Skills for the future. The Clearing House, 83(2), 39 43. doi: 10.1080/00098650903505415

Bourdieu, P. (1986). Force of law: Toward a sociology of the juridical field, the. Hastings LJ, 38, 805.

Boutelier, S. (2019). Limiting Learning Environments through Domestication. Journal of Culture and Values in Education, 2(1), 45-55. Retrieved from http://cultureandvalues.org/index.php/JCV/article/view/29

Breiner, J. M., Harkness, S. S., Johnson, C. C., \& Koehler, C. M. (2012). What is STEM? A discussion about conceptions of STEM in education and partnerships. School Science and Mathematics, 112(1), 3-11.

Brown, D. F. (2003). Urban teachers' use of culturally responsive management strategies. Theory into Practice, 42(4), 277-282. 
Corprew III, C. S., \& Cunningham, M. (2012). Educating tomorrow's men: Perceived school support, negative youth experiences, and bravado attitudes in African American adolescent males. Education and Urban Society, 44(5), 571-589.

Cottingham, M. D. (2012). Interaction ritual theory and sports fans: Emotion, symbols, and solidarity. Sociology of Sport Journal, 29(2), 168-185.

Cremin, L. A. (1970). American Education: The Colonial Experience, 1607-1783. Harper \& Row.

Creswell, J. W. (2013). Research design: Qualitative, quantitative, and mixed methods approaches. Sage publications.

Dei, G. J. S., Mazzuca, J., \& McIsaac, E. (1997). Reconstructing 'dropout': A critical ethnography of the dynamics of black students' disengagement from school. University of Toronto Press.

Emdin, C. (2010a). Science education for the hip-hop generation. Rotterdam: Sense Publishers

Emdin, C. (2010b). Affiliation and alienation: Hip-hop, rap, and urban science education. Journal of Curriculum Studies, 42(1), 1-25.

Emdin, C. (2016). For White folks who teach in the hood... and the rest of y'all too: Reality pedagogy and urban education. Beacon Press.

Emdin, C., Adjapong, E., \& Levy, I. (2016). Hip-hop based interventions as pedagogy/therapy in STEM: A model from urban science education. Journal for Multicultural Education, 10(3), 307-321.

Erbilgin, E. (2017). A Comparison of the Mathematical Processes Embedded in The Content Standards of Turkey and Singapore. Research in Social Sciences and Technology,2(1). Retrieved from http://ressat.org/index.php/ressat/article/view/39

FACT SHEET: President Obama announces over \$240 million in new STEM commitments at the 2015 White House science fair. (2018, March 23). Retrieved March 06, 2016, from https:/www.whitehouse.gov/the-press-office/2015/03/23/fact-sheet-president-obama-announcesover-240-million-new- stem-commitment.pdf

Felice, L. G. (1981). Black student dropout behavior: Disengagement from school rejection and racial discrimination. The Journal of Negro Education, 50(4), 415-424.

Ford, D. Y., \& Harris III, J. J. (1996). Perceptions and attitudes of Black students toward school, achievement, and other educational variables. Child development, 67(3), 1141-1152.

Gašević, D., Dawson, S., Rogers, T., \& Gasevic, D. (2016). Learning analytics should not promote one size fits all: The effects of instructional conditions in predicting academic success. The Internet and Higher Education, 28, 68-84.

Guba, E.G., \& Lincoln, Y.S. (1989). Fourth generation evaluation. Newbury Park, CA: Sage.

Hannafin, M. J., Hill, J. R., \& Land, S. M. (1997). Student-centered learning and interactive multimedia: Status, issues, and implication. Contemporary Education, 68(2), 94.

Hannafin, M. J., Hill, J. R., Land, S. M., \& Lee, E. (2014). Student-centered, open learning environments: Research, theory, and practice. In Handbook of Research on Educational Communications and Technology (pp. 641-651). Springer, New York, NY.

Howard, T. C. (2013). How does it feel to be a problem? Black male students, schools, and learning in enhancing the knowledge base to disrupt deficit frameworks. Review of Research in Education, 37(1), 54-86. doi:10.3102/0091732X12462985

Jaudinez, A. S. (2019). Teaching Senior High School Mathematics: Problems and Interventions. Pedagogical Research, 4(2), em0031. https://doi.org/10.29333/pr/5779

John-Steiner, V., \& Mahn, H. (1996). Sociocultural approaches to learning and development: A Vygotskian framework. Educational Psychologist, 31(3/4), 191- 206.

Kahle, J., Meece, J., \& Scantlebury, K. (2000). Urban African-American middle school science students: Does standards-based teaching make a difference? Journal of Research in Science Teaching, 27(9), 10191041. doi:10.1002/1098-2736(200011)37:9<1019::AID-TEA9>3.0.CO;2-J

Kotluk, N., \& Kocakaya, S. (2018). Culturally relevant/responsive education: What do teachers think in Turkey? Journal of Ethnic and Cultural Studies, 5(2), 98-117.

Ladson-Billings, G. (1995). But that's just good teaching! The case for culturally relevant pedagogy. Theory Into Practice, 34, 159-165.

Langdon, D., McKittrick, G., Beede, D., Khan, B., \& Doms, M. (2011, July). Stem: Good jobs now and for the future. Retrieved from http://www.esa.doc.gov/sites/default/files/reports/documents/stemfinalyjuly14_1.pdf

Lave, J., \& Wenger, E. (1991). Situated learning. Legitimate peripheral participation. Cambridge, England: Cambridge University Press. 
Lieberman, G. A., \& Hoody, L. L. (1998). Closing the achievement gap: Using the environment as an integrating context for learning. Executive Summary.

Linn, M. C., Lewis, C., Tsuchida, I., \& Songer, N. B. (2000). Beyond fourth-grade science: Why do US and Japanese students diverge? Educational Researcher, 29(3), 4-14. doi:10.3102/0013189X029003004

Maguth, B , Koskey, K . (2019). Preparing Urban Youth to Live-up to their Civic Promise? Researching Youth Positionality of Civic Engagement Using an Arts-Based Instrument. Journal of Social Studies Education Research, 10 (1), 1-37. Retrieved from http://dergipark.org.tr/jsser/issue/45447/570401

Márque, J., Peña, C., Jones, L., Orange, A., \& Simieou, F. (2018). Academic success and resiliency factors: A case study of unaccompanied immigrant children. American Journal of Qualitative Research, 2(1), $162-181$.

Maslow, A. H. (1965). Eupsychian management: A journal. Homewood: RD Irwin.

Mauch, J., \& Tarman, B. (2016). A historical approach to social studies laboratory method. Research in Social Sciences and Technology, 1(2), 55-66.

Moje, E. B., Ciechanowski, K. M., Kramer, K., Ellis, L., Carrillo, R., \& Collazo, T. (2004). Working toward third space in content area literacy: An examination of everyday funds of knowledge and discourse. Reading Research Quarterly, 39(1), 38-70. doi:10.1598/RRQ.39.1.4

Moore, J. (2018). Don't Shut Up: Why Teachers Must Defend the First Amendment in Secondary Schools. Journal of Culture and Values in Education, 1(2), 23-41. Retrieved from http://cultureandvalues.org/index.php/JCV/article/view/10

Munce, R., \& Fraser, E. (2012). Where are the stem students? Retrieved from http://www.stemconnector.org/sites/default/files/store/STEM-Students-STEM- Jobs-ExecutiveSummary.pdfhttp://www.stemconnector.org/sites/default/files/store/STEM- Students-STEM-JobsExecutive-Summary.pdf

Nouri, A., \& Sajjadi, S. M. (2014). Emancipatory Pedagogy in Practice: Aims, Principles and Curriculum Orientation. The International Journal of Critical Pedagogy, 5(2).

Ogbu, J. U. (2003). Black American students in an affluent suburb: A study of academic disengagement. New York, NY: Routledge.

Paris, D., \& Alim, H. S. (2017). Culturally sustaining pedagogies: Teaching and learning for justice in a changing world. New York, NY: Teachers College Press.

Reardon, S. F. (2011). The widening academic achievement gap between the rich and the poor: New evidence and possible explanations. Whither Opportunity, 91-116.

Ruck, M. D., \& Wortley, S. (2002). Racial and ethnic minority high school students' perceptions of school disciplinary practices: A look at some Canadian findings. Journal of Youth and Adolescence, 31(3), 185-195. doi:10.1023/A:1015081102189

Seiler, G. (2001). Reversing the "standard" direction: Science emerging from the lives of African American students. Journal of Research in Science Teaching, 38, 1000 - 1014. doi:10.1002/tea.1044

Shenton, A. K. (2004). Strategies for ensuring trustworthiness in qualitative research projects. Education for information, 22(2), 63-75.

Skiba, R. J., Michael, R. S., Nardo, A. C., \& Peterson, R. L. (2002). The color of discipline: Sources of racial and gender disproportionality in school punishment. The Urban Review, 34(4), 317-342.

Smith, L. T. (2013). Decolonizing methodologies: Research and indigenous peoples. Chicago, IL: Zed Books Ltd.

Speir, S. B., \& Simmons, L. (2016). Inquiry: An emancipatory pedagogical strategy for Bermuda schools. Voices in Education, 10.

Teale, W. H., Paciga, K. A., \& Hoffman, J. L. (2007). Beginning reading instruction in urban schools: The curriculum gap ensures a continuing achievement gap. The Reading Teacher, 61(4), 344-348. doi:10.1598/RT.61.4.8

Townsend, B. L. (2000). The disproportionate discipline of African American learners: Reducing school suspensions and expulsions. Exceptional children, 66(3), 381-391. doi:10.1177/001440290006600308

Tyack, D. B. (1974). The one best system: A history of American urban education (Vol. 95). Cambridge, MA: Harvard University Press.

U.S. Department of Education (2016) Office of Planning, Evaluation and Policy Development, Policy and Program Studies Service, The State of Racial Diversity in the Educator Workforce, Washington, D.C.

Yehya, F., Barbar, A., \& Abou Rjeily, S. (2018). Diagnosing the barriers for integrating Educational Technology in Physics courses in Lebanese secondary schools. Research In Social Sciences And Technology, 3(2), 14-39. Retrieved from http://ressat.org/index.php/ressat/article/view/337 
Warder, G. (2017). Horace Mann and the creation of the Common School. Retrieved from https://socialwelfare.library.vcu.edu/programs/education/horace-mann-creation-common-school/

Woofter, S. (2019). Book Review: Building Equity: Policies and Practices to Empower All

Learners. American Journal of Qualitative Research, 3(1), 136-139. https://doi.org/10.29333/ajqr/5815 